\title{
Study of a combined sulfur autotrophic with proton-exchange membrane electrodialytic denitrification technology: Sulfate control and $\mathrm{pH}$ balance
}

\author{
Dongjin Wan ${ }^{\mathrm{a}, \mathrm{b}}$, Huijuan Liu ${ }^{\mathrm{a}, *}$, Ruiping Liu ${ }^{\mathrm{a}}$, Jiuhui $\mathrm{Qu}^{\mathrm{a}}$ \\ a State Key Laboratory of Environmental Aquatic Chemistry, Research Center for Eco-Environmental Sciences, Chinese Academy of Sciences, Beijing 100085, China \\ ${ }^{\mathrm{b}}$ Henan University of Technology, Zhengzhou, Henan 450001, China
}

\section{A R T I C L E I N F O}

\section{Article history:}

Received 4 July 2011

Received in revised form 25 August 2011

Accepted 31 August 2011

Available online 13 September 2011

\section{Keywords:}

Proton-exchange membrane electrodialysis Autotrophic denitrification

Sulfur

Hydrogen

pH balance

\begin{abstract}
A B S T R A C T
A novel combined system established for nitrate removal from aqueous solution consisted of two parts: sulfur autotrophic denitrification and bio-electrochemical denitrification based on proton-exchange membrane electrodialysis (PEMED). The system was operated at various hydraulic retention times (HRT) and current intensities. Its optimum operation condition was also determined. The combined process had $\mathrm{pH}$ adjustment thus generating less nitrite than PEMED process. The denitrification rate of sulfur autotrophic part was dependent on HRT, while shorter HRT could reduce the sulfate generated by the sulfur autotrophic process. The denitrification rate of PEMED process depended on the applied current. For $32 \pm 1 \mathrm{mg}-\mathrm{N} / \mathrm{L}$ nitrate in influent, the optimum operation parameters of combined process were: HRT $2 \mathrm{~h}$; applied current $350 \mathrm{~mA}$. The combined reactor could achieve 95.8\% nitrate removal without nitrite accumulation, the $\mathrm{pH}$ of effluent kept neutral and the sulfate of effluent was $202.1 \mathrm{mg} / \mathrm{L}$, lower than the drinking water standard in China.
\end{abstract}

(c) 2011 Elsevier Ltd. All rights reserved.

\section{Introduction}

Significant increase of nitrate in groundwater has been observed in many areas of the world (Nolan et al., 1997). Since nitrate has a deleterious effect on human health and environment, processes for nitrate removal have gained attention in recent years (Kleinjans et al., 1991; Nolan et al., 1997). The conventional treatment methods used to remove nitrate are reverse osmosis (RO) (Brigita et al., 2009), ion exchange (IE) (Samatya et al., 2006), catalytic (Prüsse et al., 2000; Florence et al., 2001; Wan et al., 2009a) and biological (Anabela et al., 2000; Lucas et al., 2005; Liu and Koenig, 2002; Rezania et al., 2007) processes. There are some disadvantages with these methods that limit their application. For instance, both RO and IE cannot transfer nitrate into harmless nitrogen but only concentrate nitrate from water to waste brine that may pose a disposal problem for afterwards treatment. For the new method of catalytic process, although complete or partial nitrate removal is reported by the researchers Prüsse et al. (2000), Florence et al. (2001) and Wan et al. (2009a), formation of ammonia and nitrite along with nitrate reduction is an undesired consequence of this method. Besides, high costs and deactivation of catalysts limits its utilization. Biological treatment is the most favorable method for nitrate removal for its low operating and capital cost, and it has been successfully utilized in many drinking water plants in Europe (Anabela et al., 2000).

\footnotetext{
* Corresponding author. Tel./fax: +86 1062849160 .

E-mail address: hjliu@rcees.ac.cn (H. Liu).
}

Autotrophic denitrification could utilize inorganic carbon substrates (carbon dioxide or bicarbonate) as a carbon source and rely on electron donor like hydrogen or sulfur for energy. Some advantages of autotrophic over heterotrophic denitrification process are: avoiding secondary pollution of residual carbon source; low biomass yield and less sludge production (Liu and Koenig, 2002; Rezania et al., 2007).

Hydrogen is the preferred donor for autotrophic denitrification for its clean nature and low biomass yield (Rezania et al., 2007; Wan et al., 2009b):

$$
\begin{aligned}
1.06 \mathrm{NO}_{3}^{-} & +0.3 \mathrm{CO}_{2}+3.34 \mathrm{H}_{2}+1.06 \mathrm{H}^{+} \rightarrow 0.06 \mathrm{C}_{5} \mathrm{H}_{7} \mathrm{O}_{2} \mathrm{~N}+0.5 \mathrm{~N}_{2} \\
& +3.66 \mathrm{H}_{2} \mathrm{O}
\end{aligned}
$$

However, low solubility and explosive nature of hydrogen may limit its application in denitrification process. To overcome the aforementioned problems, in situ hydrogen production through electrolysis of water on cathode surface has been developed (Sakakibara and Kuroda, 1993). Autotrophic denitrifying microorganisms were immobilized toward the surface of cathode thus they could utilize $\mathrm{H}_{2}$ conveniently for nitrate reduction. Recently, many efforts have been reported to improve the design for the efficient and economical removal of nitrate from water by this bioelectrochemical method (Prosnansky et al., 2002; Park et al., 2005; Ghafari et al., 2008). The novel proton-exchange membrane electrodialysis denitrification (PEMED) system was first proposed and explored in batch mode in 2010 (Wan et al., 2010). In such system, the proton-exchange membrane was used to transfer current and exclude 
oxygen or other oxidative chemicals generated in the anode reaction; the $\mathrm{H}_{2}$ generated by the cathode was utilized by autotrophic denitrifying microorganisms directly to reduce nitrate. Compared to other bioelectrochemical system with non-separation between anode and cathode, the PEMED system could be operated under higher applied current and biomass concentration, thus exhibiting high removal capacity (Wan et al., 2010).

Sulfur was also used as electron donor for autotrophic denitrification. Contrary to hydrogen autotrophic denitrification, sulfur autotrophic denitrification consumes alkalinity thus resulting in a decrease of $\mathrm{pH}$ with generated sulfate as a by-product (Koenig and Liu, 2001):

$$
\begin{aligned}
1.06 \mathrm{NO}_{3}^{-} & +1.11 \mathrm{~S}+0.3 \mathrm{CO}_{2}+0.785 \mathrm{H}_{2} \mathrm{O} \rightarrow 0.06 \mathrm{C}_{5} \mathrm{H}_{7} \mathrm{O}_{2} \mathrm{~N}+0.5 \mathrm{~N}_{2} \\
& +1.11 \mathrm{SO}_{4}^{2-}+1.16 \mathrm{H}^{+}
\end{aligned}
$$

In this study, a novel MBR based on combination of sulfur autotrophic denitrification and PEMED system was developed for continuous experiment. The main purpose for combination was to realize sulfate control and $\mathrm{pH}$ balance during autotrophic denitrification process. In such combined processes, the sulfate concentration could be controlled by the nitrogen load of sulfur autotrophic denitrification part, and the $\mathrm{H}^{+}$generated in sulfur denitrification could be consumed by the bioelectrochemical hydrogen denitrification thus alkalinity generation and consumption could be balanced. The main objectives of the present investigation were: (1) to evaluate whether sulfur denitrification process could collaborate with PEMED system; (2) to explore method for sulfate control; (3) to uncover $\mathrm{pH}$ variation rule and its effect on nitrate removal in combined process. The system was operated at various HRT and current intensities. Its optimum operation parameters were also determined in this study.

\section{Methods}

\subsection{Experimental apparatus}

The experimental apparatus used in this study is shown schematically in Fig. 1. The reactor consisted of two parts: sulfur autotrophic denitrification part (mentioned as S-part) and bioelectrochemical denitrification part based on proton-exchange membrane electrodialysis (mentioned as E-part), and the total effective liquid volume of the reactor was $4.0 \mathrm{~L}$.

The S-part was a plexiglas column had an i.d. of $12 \mathrm{~cm}$ and a height of $40 \mathrm{~cm}$, where $30 \mathrm{~cm}$ of sulfur part was packed with sulfur granules (2-3 mm diameter Yanshan pc.Co., Ltd., Beijing, China). The porosity of S-part is $30 \%$, thus the effective pore water volume of S-part was $1.0 \mathrm{~L}$.

The E-part constructed from the plexiglas cube had a side length of $20 \mathrm{~cm}$. The anode cell and cathode cell were separated by a proton-exchange membrane (GEFC-107, GEFC, China). The membrane was located in the middle of the cube. The height of electrolyte solution was $15 \mathrm{~cm}$, thus the effective volume of each cell was $3.0 \mathrm{~L}$. The cathode was $\mathrm{Cu}$ plate with $270 \mathrm{~cm}^{2}$ $(18 \times 15 \mathrm{~cm})$ effective surface area and the anode was a DSA (dimensionally stable anode) electrode. Direct current was supplied by silicon rectifier (Model DH1718E-4, Beijing Dahua Electronic Instruments Group, Beijing, China). The electrolyte of each cell was continuously mixed by a recirculation pump. And the suspended autotrophic denitrifying microorganisms were mixed thoroughly in the cathode cell. The E-part was connected with a micro filtration (MF) module (membrane material: PVDF, hollow fiber, $\Phi 50 \times 386$ mm, Model MOFIB, Motimo Membrane, Tianjin, China) with nominal pore size of $0.2 \mu \mathrm{m}$, total surface area of $0.2 \mathrm{~m}^{2}$ and the design flux of membrane module was $50-60 \mathrm{~L} / \mathrm{m}^{2} \mathrm{~h}$. The transmembrane pressure (TMP) was monitored daily to measure the extent of membrane fouling. Additionally, dissolved oxygen was purged by $200 \mathrm{ml} / \mathrm{min} \mathrm{N}_{2}$ in feed tank.

The synthetic contaminated water was prepared from tap water using sodium nitrate $\left(\mathrm{NaNO}_{3}\right)$ as the contaminant. And the initial $\mathrm{NO}_{3}^{-}-\mathrm{N}$ concentration was $32 \pm 1 \mathrm{mg} / \mathrm{L}, \mathrm{SO}_{4}^{2-}$ was $56.3 \mathrm{mg} / \mathrm{L}$, and the $\mathrm{pH}$ of influent maintained at $7.40 \pm 0.10$. Nutrient such as $\mathrm{KH}_{2} \mathrm{PO}_{4} 1 \mathrm{mmol} / \mathrm{L}, \mathrm{K}_{2} \mathrm{HPO}_{4} 1 \mathrm{mmol} / \mathrm{L}, \mathrm{Na}_{2} \mathrm{CO}_{3} 1 \mathrm{mmol} / \mathrm{L}$ was also added in the influent. The reactor was operated under room temperature $20 \pm 1^{\circ} \mathrm{C}$.

\subsection{Bacterial inoculation and acclimation}

For S-part and E-part, bacteria was inoculated and acclimated according to the method described in detail in previous publication Wan et al. (2009b, 2010), respectively. Biofilm was formed on the sulfur granule surface in about 20 days. Hydrogen autotrophic bacteria were acclimated by sparging $\mathrm{H}_{2}$ continuously for 2 weeks.

\subsection{Experimental procedure}

The removal efficiency and sulfate generation rule of S-part was determined as the hydraulic retention time (HRT) of S-part maintained at $1.25 \mathrm{~h}, 1.00 \mathrm{~h}, 0.75 \mathrm{~h}, 0.50 \mathrm{~h}$ and $0.25 \mathrm{~h}$.

For E-part, the concentration of acid added into anode cell to keep the cathodic aqueous $\mathrm{pH}$ neutral was determined firstly through a set of experiments. $\mathrm{pH}$ variation of the cathodic cell under $0.01-0.30 \mathrm{~mol} / \mathrm{L} \mathrm{H}_{2} \mathrm{SO}_{4}$ addition in anodic cell was measured for $6.00 \mathrm{~h}$ electrodialysis process. The experimental details were: initial pH 7.40, applied current $500 \mathrm{~mA}$, HRT $3.00 \mathrm{~h}$. The applicable operation condition of E-part was investigated at the operation stage, the HRT of E-part was maintained at $5.00 \mathrm{~h}, 4.00 \mathrm{~h}, 3.00 \mathrm{~h}$, $2.00 \mathrm{~h}, 1.25 \mathrm{~h}$ and $0.83 \mathrm{~h}$ for 20 days each to investigate the performance of applied current under different HRT. Direct currents were applied to the reactor sequentially: $200-400 \mathrm{~mA}$ for HRT of $5.00 \mathrm{~h}$, $4.00 \mathrm{~h}$ and $3.00 \mathrm{~h} ; 500-700 \mathrm{~mA}$ for HRT $=2.00 \mathrm{~h} ; 850-1000 \mathrm{~mA}$ for $\mathrm{HRT}=1.25 \mathrm{~h}$ and $1000-1400 \mathrm{~mA}$ for HRT $=0.83 \mathrm{~h}$. Initial biomass for HRT of $5.00 \mathrm{~h}, 4.00 \mathrm{~h}$ and $3.00 \mathrm{~h}$ was $1.0 \mathrm{~g} / \mathrm{L}$. And for HRT of $2 \mathrm{~h}, 1.25 \mathrm{~h}$ and $0.83 \mathrm{~h}$, initial biomass increased to $2.0 \mathrm{~g} / \mathrm{L}, 3.0 \mathrm{~g} / \mathrm{L}$ and $4.0 \mathrm{~g} / \mathrm{L}$, respectively.

The combined reactor including $\mathrm{S}+\mathrm{E}$ process was also performed to confirm its ability for nitrate removal. The HRT of combined reactor was maintained at $5.00 \mathrm{~h}, 4.00 \mathrm{~h}, 3.00 \mathrm{~h}, 2.00 \mathrm{~h}$ and $1.00 \mathrm{~h}$. The removal efficiency of each part was investigated respectively. And the current under different HRT applied periodically: 0-200 mA for HRT of $5.00 \mathrm{~h}, 4.00 \mathrm{~h}$ and $3.00 \mathrm{~h} ; 300-500 \mathrm{~mA}$ for $\mathrm{HRT}=2.00 \mathrm{~h}$ and $1000-1400 \mathrm{~mA}$ for $\mathrm{HRT}=1.00 \mathrm{~h}$. Initial biomass for HRT of $5.00 \mathrm{~h}, 4.00 \mathrm{~h}$ and $3.00 \mathrm{~h}$ was $1.0 \mathrm{~g} / \mathrm{L}$. And for HRT of $2.00 \mathrm{~h}$ and $1.00 \mathrm{~h}$, initial biomass increased to $3.0 \mathrm{~g} / \mathrm{L}$ and $4.0 \mathrm{~g} / \mathrm{L}$, respectively.

Under each HRT and current, the system ran and stabilized for more than 2 days until steady-state condition was achieved. Optimum operation condition was determined at different HRT with minimum applied current to achieve more than $90 \%$ nitrate removal efficiency.

\subsection{Analytical methods}

The $\mathrm{NO}_{3}^{-}-\mathrm{N}, \mathrm{NO}_{2}^{-}-\mathrm{N}, \mathrm{SO}_{4}^{2-} \mathrm{pH}$ and ORP of the influent, effluent from S-part and E-part was measured at each steady-state condition. Samples were passed through $0.45 \mu \mathrm{m}$ membrane for analysis. The concentrations of $\mathrm{NO}_{3}^{-}-\mathrm{N}, \mathrm{NO}_{2}^{-}-\mathrm{N}$ and $\mathrm{SO}_{4}^{2-}$ were determined by ion chromatograph (Dionex 2000, USA). The $\mathrm{pH}$ was measured by multiparameters portable instruments $(\mathrm{HACH}$ Sension, USA). 


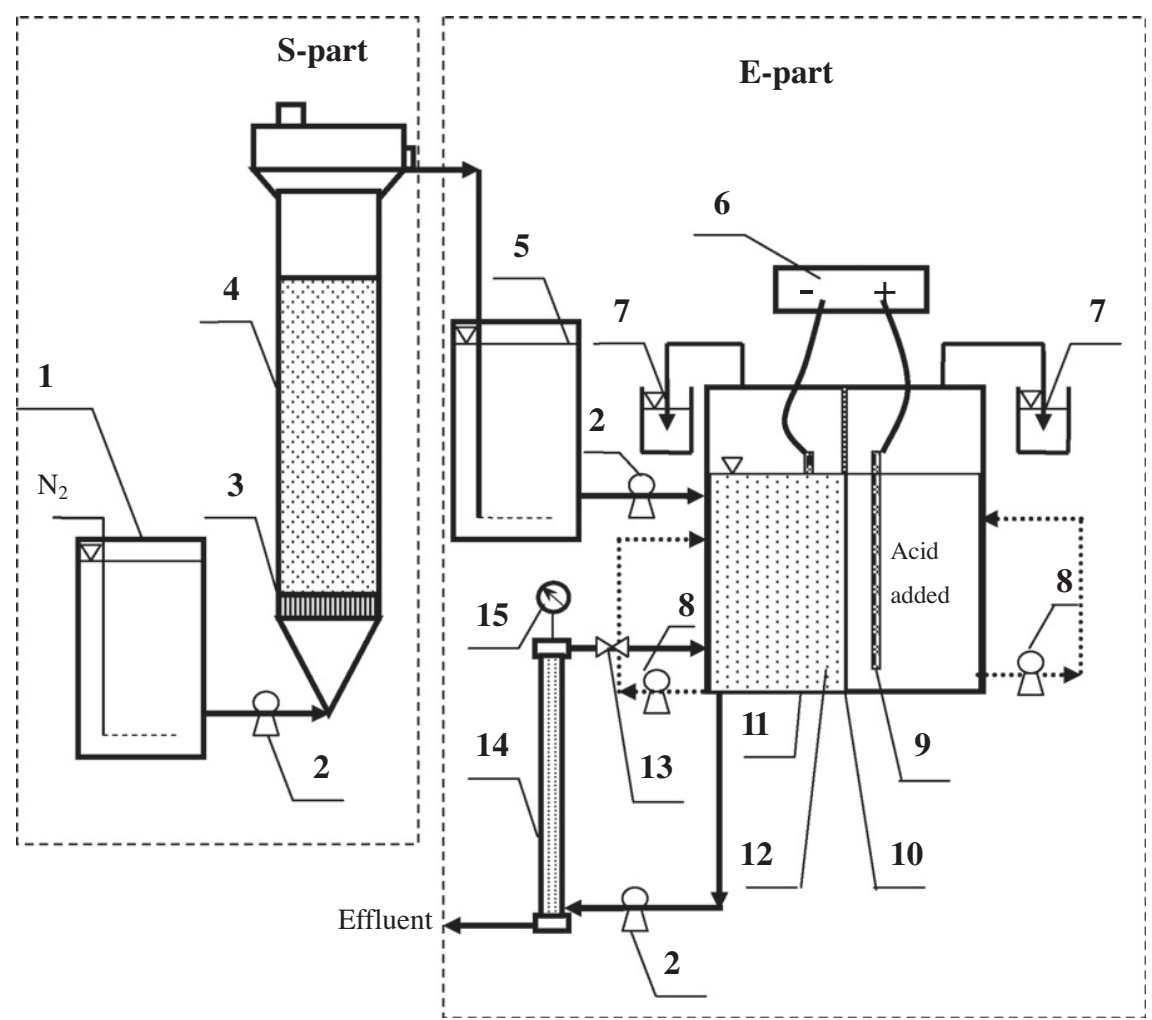

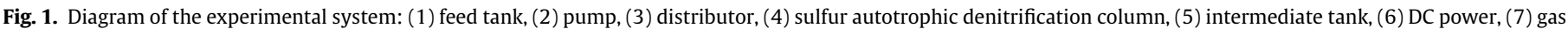

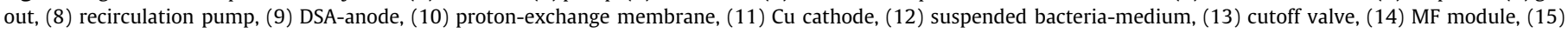
pressure gauge.

\section{Results and discussion}

\subsection{Performance of S-part}

\subsubsection{Removal efficiency of S-part}

In Erkan Sahinkaya et al.'s study (Sahinkaya et al., 2011), a membrane biofilm reactor has been developed for sulfide-oxidizing. Decreasing the HRT from $3.8 \mathrm{~h}$ to $1.6 \mathrm{~h}$, the accompanying sulfide load increased from $22.7 \mathrm{~g} / \mathrm{m}^{2} \mathrm{~d}$ to $48.6 \mathrm{~g} / \mathrm{m}^{2} \mathrm{~d}$, caused the sulfide oxidation efficiency to decline from $99 \%$ to $40 \%$. In this study, the similar phenomenon occurred, nitrate removal rate of S-part was controlled by corresponding reaction time (as well as HRT of S-part). Table 1 lists the nitrate removal rate of S-part under different HRT. As HRT shortened from $1.25 \mathrm{~h}$ to $0.25 \mathrm{~h}$, the nitrogen volume-loading rate of S-part increased from $0.61 \mathrm{~kg}-\mathrm{N} / \mathrm{m}^{3} \mathrm{~d}$ to $3.07 \mathrm{~kg}-\mathrm{N} / \mathrm{m}^{3} \mathrm{~d}$, and the removal rate of S-part decreased from $98.4 \%$ to $31.2 \%$. As well, nitrite concentration continued increasing in the effluent of S-part, about $3.50 \mathrm{mg}-\mathrm{N} /$ L for HRT $0.25 \mathrm{~h}$.

The kinetic of sulfur autotrophic denitrification column has been studied in recent years. As reported (Wang, 1998; Koenig and Liu, 2001; Moon et al., 2004), the Zero-order and Half-order bulk reaction kinetics model could be used to fit nitrate removal in sulfur packed column.
Zero-order bulk reaction: Based on the assumption that sulfur as substrate was sufficient and there was no mass transfer limitation in the biofilm on the sulfur surface.

$$
C=C_{0}-K_{0 v} T
$$

Half-order bulk reaction: Based on the assumption that the nitrate concentration was not high that it could not penetrate the biofilm.

$C=\left(C_{0}^{1 / 2}-\frac{1}{2} K_{\frac{1}{2} v} T\right)^{2}$

where $C(\mathrm{mg}-\mathrm{N} / \mathrm{L})$ is the concentration of effluent nitrate at reaction time $T(\mathrm{~h}), C_{0}(\mathrm{mg}-\mathrm{N} / \mathrm{L})$ is the initial concentration of nitrate; $K_{0 v}$ is the zero-order reaction rate constant per unit biofilm area $(\mathrm{mg} /$ $\mathrm{dm}^{2} \mathrm{~h}$ ); $K_{\frac{1}{2}} v$ is the half-order reaction rate constant per unit biofilm area $\left(\mathrm{mg}^{1 / 2} / \mathrm{dm}^{1 / 2} \mathrm{~h}\right) ; T(\mathrm{~h})$ is the reaction time (equals to HRT of Spart) which can be calculated by flux and relevant effective liquid volume of S-part.

Table 2 lists the calculated parameters and correlation coefficients of experimental data fitted to the two kinetics model. As can be seen in Table 2, the experimental data are in better agreement with the Half-order bulk reaction kinetics model, the correlation coefficient $R^{2}$ shows higher correlation, suggesting that the reaction rate appear to be controlled by the mass-transfer between biofilm on the sulfur surface.

Table 1

Nitrate removal efficiency and $\mathrm{SO}_{4}^{2-}$ generation of S-part under different HRT.

\begin{tabular}{|c|c|c|c|c|c|}
\hline HRT of S-part (h) & Nitrate removal rate (\%) & $\mathrm{NO}_{3}^{-}$in effluent (mg-N/L) & $\mathrm{NO}_{2}^{-}$in effluent (mg-N/L) & $\mathrm{SO}_{4}^{2-}$ generated by S-part $(\mathrm{mg} / \mathrm{L})$ & $\mathrm{SO}_{4}^{2-}$ in the effluent $(\mathrm{mg} / \mathrm{L})$ \\
\hline 1.25 & 98.4 & 0.51 & 0.08 & 222.5 & 278.8 \\
\hline 1.00 & 90.0 & 3.20 & 0.51 & 210.6 & 266.9 \\
\hline 0.75 & 76.4 & 7.55 & 2.01 & 181.3 & 237.6 \\
\hline 0.50 & 55.3 & 14.30 & 2.83 & 145.8 & 202.1 \\
\hline 0.25 & 31.2 & 22.02 & 3.50 & 53.9 & 110.2 \\
\hline
\end{tabular}


Table 2

Kinetics parameters and correlation coefficients $\left(R^{2}\right)$ for the two kinetic models.

\begin{tabular}{llll}
\hline $\begin{array}{l}\text { Kinetics coefficients kinetics } \\
\text { model }\end{array}$ & $\begin{array}{l}C_{0 \text { cal }}\left(\mathrm{NO}_{3}^{-}-\mathrm{N}\right. \\
\mathrm{mg} / \mathrm{L})\end{array}$ & $\begin{array}{l}K_{0 v} \text { or } \\
\frac{1}{2} K_{\frac{1}{2} v}\end{array}$ & \\
\hline$C=C_{0}-K_{0 v} T$ & 29.03 & 25.22 & 0.9589 \\
$C=\left(C_{0}^{1 / 2}-\frac{1}{2} K_{\frac{1}{2} v} T\right)^{2}$ & 32.4 & 3.94 & 0.9994 \\
\hline
\end{tabular}

\subsubsection{Sulfate in the effluent}

From the kinetics study of S-part, it could be speculated that the sulfate generated by sulfur autotrophic denitrification process was controlled by the reaction time (equals to HRT of S-part) as well as the amount of reduced $\mathrm{NO}_{3}^{-}-\mathrm{N}$ of S-part.

Sulfate generated by S-part was investigated at various HRT. As is shown in Table 1, sulfate concentration was largely affected by HRT. With shortening of HRT, the nitrate removal efficiency of Spart was decreased, and the sulfate concentration exhibited a decreasing tendency. The sulfate in effluent decreased from $278.8 \mathrm{mg} / \mathrm{L}$ to $110.2 \mathrm{mg} / \mathrm{L}$ with HRT shortened from $1.25 \mathrm{~h}$ to $0.25 \mathrm{~h}$. By subtracting the average sulfate concentration in influent, the sulfate generated by S-part was obtained. As can be seen from Table 2, the sulfate generated by S-part decreased from $222.5 \mathrm{mg} / \mathrm{L}$ to $53.9 \mathrm{mg} / \mathrm{L}$ when HRT shortened from $1.25 \mathrm{~h}$ to $0.25 \mathrm{~h}$. The concentration ratio of increased sulfate to reduced $\mathrm{NO}_{3}^{-}-\mathrm{N}(\mathrm{m} / \mathrm{m}$ : $\mathrm{SO}_{4}^{2-} / \mathrm{NO}_{3}^{-}-\mathrm{N}$ ) has an average value of 7.08 , close to the stoichiometric value 7.18 (Koenig and Liu, 2001).

\subsection{Performance of E-part}

\subsubsection{Determination of acid concentration in anode cell}

Batch mode study showed that the $\mathrm{pH}$ of cathode cell increased directly without acid supplement in anode during electrodialysis process (Wan et al., 2010). Since the reported suitable $\mathrm{pH}$ for biological denitrification is 7.0-8.0 (Kurt et al., 1987; Mateju et al., 1992; Haugen et al., 2002), it was essential to add acid into anode cell to keep $\mathrm{pH}$ in cathode cell neutral. Acid concentration in anode cell was determined through a set of experiments. Effect of $\mathrm{H}_{2} \mathrm{SO}_{4}$ concentration $(0.01-0.30 \mathrm{~mol} / \mathrm{L})$ in anode cell on $\mathrm{pH}$ of effluent from cathode cell was shown in Fig. 2. It could be noticed that without acid supplement in cathode cell, the $\mathrm{pH}$ of effluent from cathode cell increased gradually. After $6 \mathrm{~h}$ electrodialysis, the effluent $\mathrm{pH}$ of cathode cell increased from 7.40 to 10.50 . With the acid

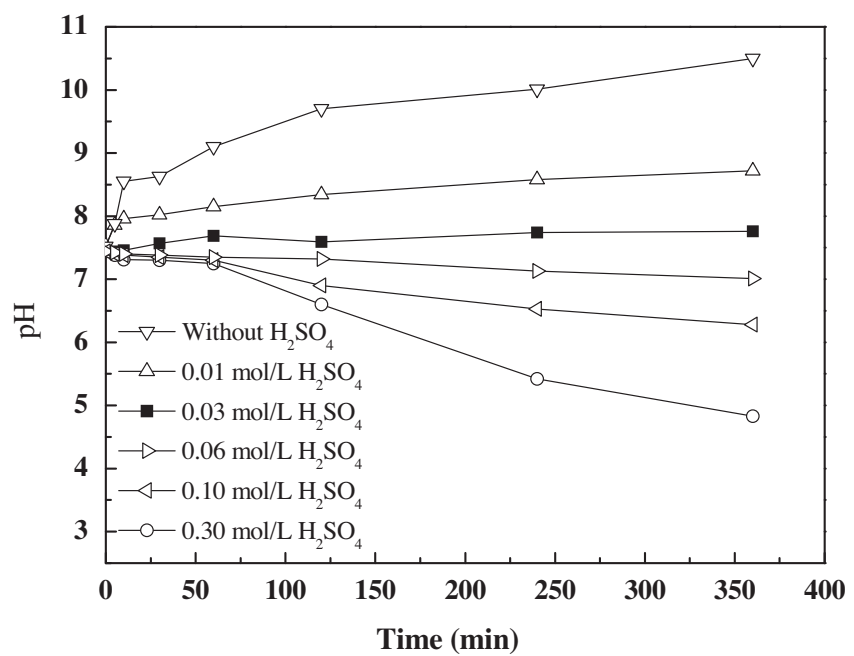

Fig. 2. Effect of $\mathrm{H}_{2} \mathrm{SO}_{4}$ concentration $(0.01-0.30 \mathrm{~mol} / \mathrm{L}$ ) in anode cell on $\mathrm{pH}$ of effluent from cathode cell (initial $\mathrm{pH}$ of cathode cell 7.40, applied current $500 \mathrm{~mA}$, HRT $3 \mathrm{~h}$, acid was added into anode cell without microorganisms in cathode cell). supplement in cathode cell, the pH increasing tendency was prohibited indicating that the dialysis of the $\mathrm{H}^{+}$concentration gradient between the two separate cells could balance the inadequate proton transfer during the electrodialysis process. It could be seen in Fig. 2, as acid concentration increased from $0.01 \mathrm{~mol} / \mathrm{L}$ to $0.03 \mathrm{~mol} / \mathrm{L}$, the $\mathrm{pH}$ of effluent remained closer to neutral. It was indicated that $0.03 \mathrm{~mol} / \mathrm{L}$ was a suitable concentration of $\mathrm{H}_{2} \mathrm{SO}_{4}$ in anode cell, during $6 \mathrm{~h}$ electrodialysis, the $\mathrm{pH}$ of effluent from cathode cell was kept between 7.40 and 7.80. When $\mathrm{H}_{2} \mathrm{SO}_{4}$ concentration further increased to $0.06 \mathrm{~mol} / \mathrm{L}$ and $0.10 \mathrm{~mol} / \mathrm{L}$, the $\mathrm{pH}$ decrease of cathode cell was observed. After $6 \mathrm{~h}$ reaction, the effluent $\mathrm{pH}$ from the cathode cell was 7.01 for $0.06 \mathrm{~mol} / \mathrm{L} \mathrm{H}_{2} \mathrm{SO}_{4}$ and 6.28 for $0.10 \mathrm{~mol} / \mathrm{L} \mathrm{H}_{2} \mathrm{SO}_{4}$ added into anode cell. When $0.30 \mathrm{~mol} / \mathrm{L} \mathrm{H}_{2} \mathrm{SO}_{4}$ was added in anode cell, owing to excessive transport of $\mathrm{H}^{+}$, the $\mathrm{pH}$ of effluent from cathode cell decreased gradually. After $6 \mathrm{~h}$ reaction, the effluent $\mathrm{pH}$ from the cathode cell was below 5.0.

\subsubsection{Effect of current on nitrate removal of E-part under different HRT}

Applied current determined the rate of donor $\left(\mathrm{H}_{2}\right)$ supply and had a significant effect on denitrification rate. The applied current as a function of $\mathrm{NO}_{3}^{-}-\mathrm{N}$ and $\mathrm{NO}_{2}^{-}-\mathrm{N}$ concentration in effluent under each HRT is shown in Fig. 3.

As HRT of E-part shortened from $5.00 \mathrm{~h}$ to $0.83 \mathrm{~h}$, the nitrate volume-loading increased, thus higher applied current was in need. From Fig. 3 it can be seen that low current $(<400 \mathrm{~mA})$ was suitable for nitrate removal when HRT ranged from $5.00 \mathrm{~h}$ to $3.00 \mathrm{~h}$. While HRT further shortened from $2.00 \mathrm{~h}$ to $0.83 \mathrm{~h}$, higher applied current was needed for complete denitrification. The optimum currents determined for more than $90 \%$ nitrate removal efficiency at HRT $5.00 \mathrm{~h}, 4.00 \mathrm{~h}, 3.00 \mathrm{~h}, 2.00 \mathrm{~h}, 1.25 \mathrm{~h}$ and $0.83 \mathrm{~h}$ were $250 \mathrm{~mA}$, $300 \mathrm{~mA}, 400 \mathrm{~mA}, 550 \mathrm{~mA}, 900 \mathrm{~mA}, 1300 \mathrm{~mA}$, respectively. At HRT of $1.25 \mathrm{~h}$ and $0.83 \mathrm{~h}$, nitrite accumulation was about $0.50 \mathrm{mg}-\mathrm{N} / \mathrm{L}$ and $0.77 \mathrm{mg}-\mathrm{N} / \mathrm{L}$ under high applied current $(1000 \mathrm{~mA}$ and $1400 \mathrm{~mA}$ ), respectively. High applied current could not diminish nitrite, this phenomena was related to $\mathrm{pH}$ in effluent which is discussed more in-depth in Section 3.3.2.

\subsubsection{Efficiency of current under different HRT}

Efficiency of current $\left(I_{\mathrm{E}}\right)$ under various HRT is shown in Fig. 4. Effective current which could indicate efficiency of applied current, was calculated using the following equation:

$I_{E}=\left[\left(C_{\mathrm{NO}_{3}^{-}, \text {in }}-C_{\mathrm{NO}_{3}^{-}, \text {eff }}\right) \times 5+\left(C_{\mathrm{NO}_{2}^{-}, \text {in }}-C_{\mathrm{NO}_{2}^{-}, \text {eff }}\right) \times 3\right] \times F \times V / H R T$

where $C$ is nitrate or nitrite concentration (mmol-N/L), $F$ is Faraday constant (26.8 $\mathrm{mA} \mathrm{h} / \mathrm{mmol}), V$ is the effective volume of reactor (L). The electric current efficiency can be calculated as: $E_{i}=I_{E} / I$. It can be seen from Fig. 4 that efficiency of optimum current at different HRT ranges from $68 \%$ to $77 \%$. It was indicated that the majority of hydrogen $(>68 \%)$ generated by cathode was utilized by bacteria for autotrophic denitrification.

In addition, the cell assimilation was considerably slow in this study. By testing VSS variation during the operation period, the observed yield of $0.33 \mathrm{mg}$ VSS per mg-N removed was calculated thus the average bacterial yield coefficient was 0.041 , lower than equation assumption 0.057 (Wan et al., 2009b). The micro filtration (MF) module cleaning using $0.05 \mathrm{M} \mathrm{NaOH}$ and $0.2 \% \mathrm{NaClO}$ (calculated by effective chlorine) carried out every 20 days was so effective that the operation continued over 100 days under low pressure. The trans-membrane pressure was considerably low in this study $\left(<2 \times 10^{4} \mathrm{~Pa}\right)$.

\subsection{Performance of the combined system}

\subsubsection{Removal efficiency of the combined system}

The performance of combined $\mathrm{S}+\mathrm{E}$ process was comparably studied with E process. For E-process, E-part was set as an 

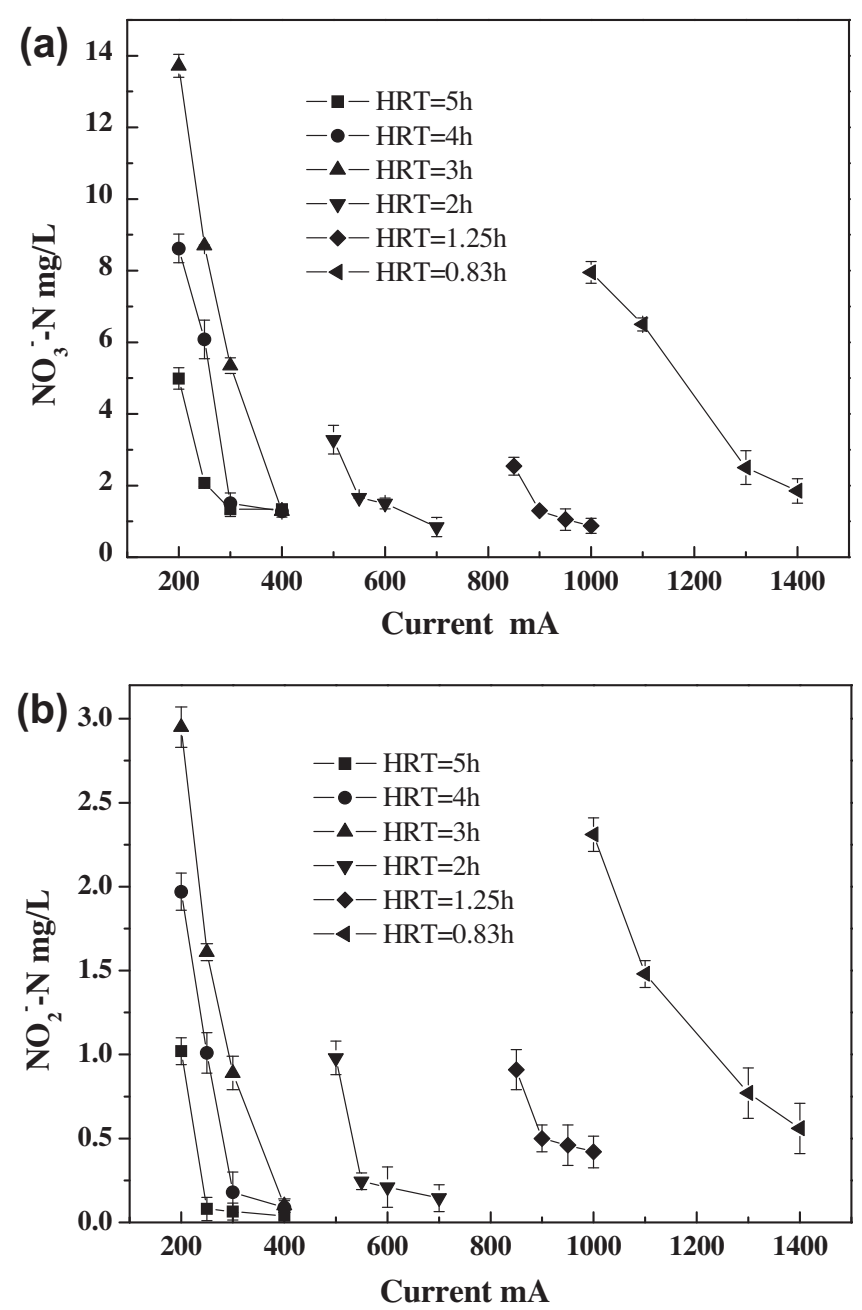

Fig. 3. The applied current as a function of (a) $\mathrm{NO}_{3}^{-}-\mathrm{N}$ and (b) $\mathrm{NO}_{2}^{-}-\mathrm{N}$ concentration in effluent under each HRT for E process.

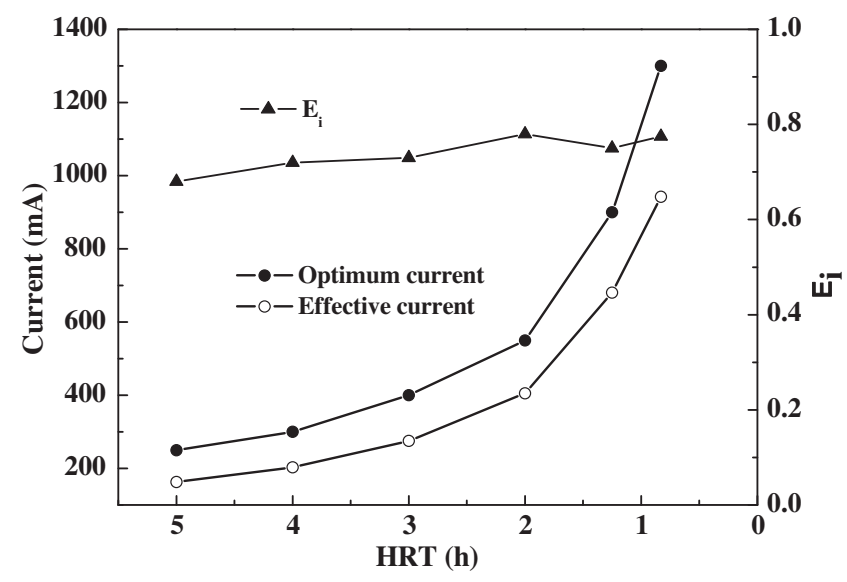

Fig. 4. Efficiency of optimum current as a function of HRT for E process.

independent reactor not a partial reactor. And the HRT of S + E process refers to the HRT of combined reactor including both E part and S part; the HRT of E-process means HRT of E-part alone. Nitrate and nitrite concentration in effluent of each process were plotted as a function of HRT in Fig. 5(a). Furthermore, the corresponding optimum applied currents for S + E process and its efficiency of each HRT are shown in Fig. 5(b). It could be seen that compared with E process, the combined $\mathrm{S}+\mathrm{E}$ process could lessen nitrite accumulation significantly. For E process, as HRT shortened from $5.00 \mathrm{~h}$ to $2.00 \mathrm{~h}$, the nitrite concentration exceeded $0.20 \mathrm{mg}-\mathrm{N} / \mathrm{L}$. As HRT further shortened from $1.25 \mathrm{~h}$ to $0.83 \mathrm{~h}$, the average nitrite concentration achieved $0.50 \mathrm{mg}-\mathrm{N} / \mathrm{L}$ and $0.77 \mathrm{mg}-\mathrm{N} / \mathrm{L}$, respectively. However, the nitrite concentration of the combined $\mathrm{S}+\mathrm{E}$ process maintained at a low level $(<0.15 \mathrm{mg}-\mathrm{N} / \mathrm{L})$ over the entire studied HRT range (5.00-1.00 h). The reason was related to the effluent $\mathrm{pH}$ of both processes and is further discussed in Section 3.3.2.

In the combined process, S-part exhibited high nitrate removal efficiency $(\geqslant 76.4 \%$ ) when HRT varied from $5.00 \mathrm{~h}$ to $3.00 \mathrm{~h}$ (corresponding HRT of S-part varied from $1.25 \mathrm{~h}$ to $0.75 \mathrm{~h}$ ). Consequently, the optimum current applied to E-part to maintain over $90 \%$ nitrate removal efficiency of the whole process was low: $20 \mathrm{~mA}$ for HRT $5.00 \mathrm{~h}, 50 \mathrm{~mA}$ for HRT $4.00 \mathrm{~h}$ and $130 \mathrm{~mA}$ for HRT $3.00 \mathrm{~h}$. While HRT further shortened from $3.00 \mathrm{~h}$ to $1.00 \mathrm{~h}$, the nitrate removal rate of S-part decreased sharply, $55.3 \%$ for HRT $2.00 \mathrm{~h}$ and $31.2 \%$ for HRT $1.00 \mathrm{~h}$ (corresponding HRT of S-part was $0.50 \mathrm{~h}$ and $0.25 \mathrm{~h}$, respectively). Therefore, the nitrate-load of E-part increased directly, and the optimum current raised to $350 \mathrm{~mA}$ for HRT $2.00 \mathrm{~h}$ and $1300 \mathrm{~mA}$ for HRT $1.00 \mathrm{~h}$. Corresponding efficiency of current ranged from $66 \%$ to $81 \%$, consistent with Epart study.

When HRT of the combined process shortened within $3.00 \mathrm{~h}$ (corresponding HRT of $\mathrm{S}$-part $\leqslant 0.75 \mathrm{~h}$ ), the sulfate concentration of effluent was less than $250 \mathrm{mg} / \mathrm{L}$, meeting the drinking water standard for sulfate from the Chinese Environmental Protection Agency.
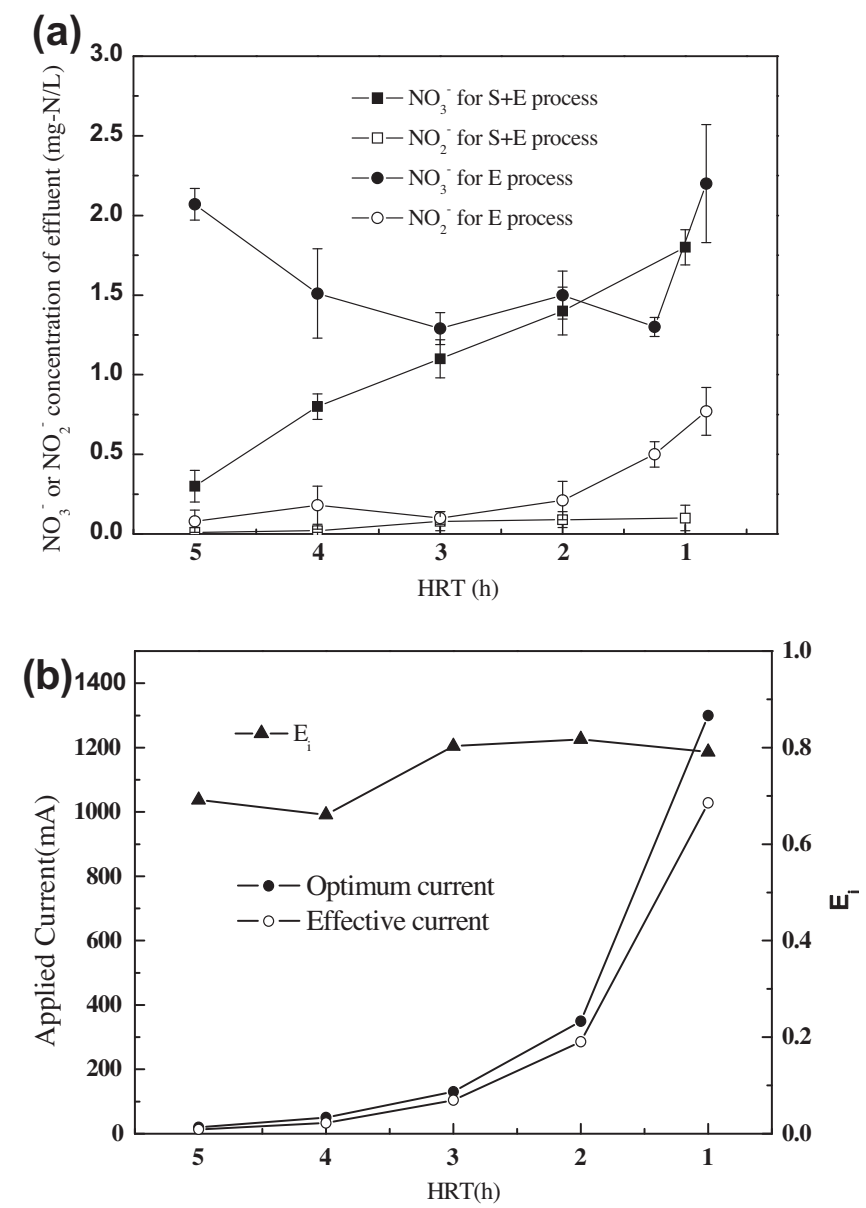

Fig. 5. (a) The nitrate and nitrite concentration of effluent in both combined $S+E$ process and E process under optimum applied current of each HRT; (b) corresponding optimum applied currents and its efficiency of each HRT for S + E process. 


\subsection{2. $\mathrm{pH}$ banlance}

$\mathrm{pH}$ is an important parameter during denitrification process. As reported (Kurt et al., 1987; Mateju et al., 1992; Haugen et al., 2002), the suitable $\mathrm{pH}$ for biological denitrification was in the range of 7.0-8.0. When $\mathrm{pH}$ exceeded 8.6, significant decrease for nitrate removal and dramatic nitrite accumulation was observed (Lee and Rittmann, 2000, 2003). The $\mathrm{pH}$ variation in effluent of both $\mathrm{E}$ process and $\mathrm{S}+\mathrm{E}$ process under optimum applied current of each HRT is presented in Fig. 6(a). As can be seen in Fig. 6(a), the $\mathrm{pH}$ of effluent for $\mathrm{E}$ process is higher than $\mathrm{S}+\mathrm{E}$ process over the entire studied HRT range, indicating that the $\mathrm{H}^{+}$generated by S-part could be consumed by E-part.

Based on calculation of $\mathrm{H}^{+}$balance between the two autotrophic denitrification process, when the nitrate removal of E-part to Spart $<1.09$ (Wan et al., 2009b), the effluent $\mathrm{pH}$ would be lower than in the influent. This indicated that the $\mathrm{H}^{+}$formed by S-part cannot be completely consumed by E-part. When the nitrate removal of $\mathrm{E}$ part to S-part $>1.09$, the effluent $\mathrm{pH}$ would be higher than influent because $\mathrm{H}^{+}$generated by $\mathrm{S}$-part was inadequate for E-part consumption.

For E process, the pH of effluent exceeded 8.7 as HRT shortened to $1.25 \mathrm{~h}$ and $0.83 \mathrm{~h}$, resulting nitrite accumulation was as follows, $0.50 \mathrm{mg}-\mathrm{N} / \mathrm{L}$ for $1.25 \mathrm{~h}$ and $0.77 \mathrm{mg}-\mathrm{N} / \mathrm{L}$ for $0.83 \mathrm{~h}$.

Comparably, the effluent $\mathrm{pH}$ for combined $\mathrm{S}+\mathrm{E}$ process over the entire studied HRT range was lower than 8.6 and nitrite accumulation was not observed. The nitrate removal ratio of E-part was $1.2 \%$,
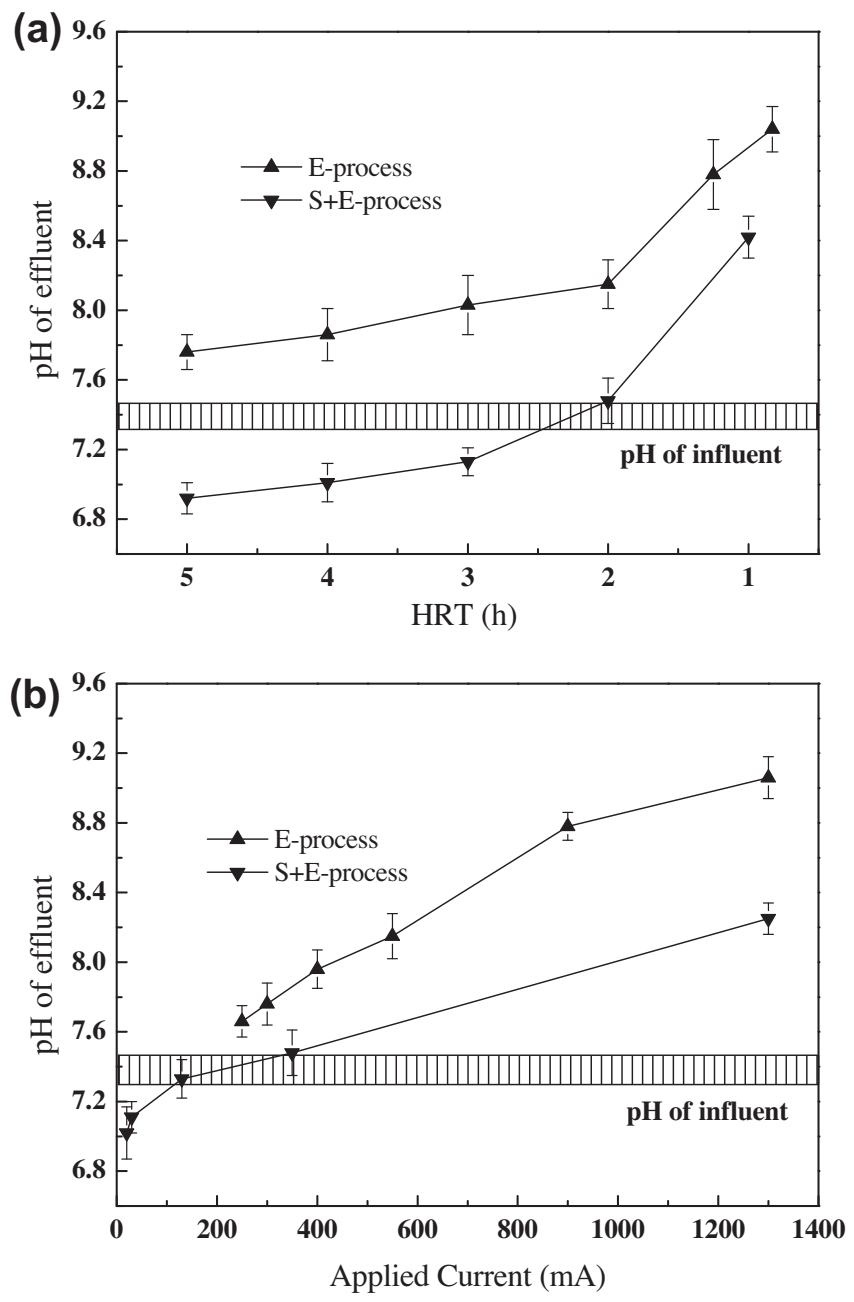

Fig. 6. (a) The $\mathrm{pH}$ variation in effluent of both $\mathrm{S}+\mathrm{E}$ process and $\mathrm{E}$ process under optimum applied current of each HRT; (b) the $\mathrm{pH}$ of effluent as a function of applied current at HRT $=2 \mathrm{~h}$.
7.5\% and $20.2 \%$ when HRT was $5.00 \mathrm{~h}, 4.00 \mathrm{~h}$ and $3.00 \mathrm{~h}$, respectively. The corresponding nitrate removal ratio of S-part was $98.4 \%, 90.0 \%$ and $76.4 \%$. Since the nitrate removal ratio of E-part to S-part was $<1.09$ when HRT was $5.00 \mathrm{~h}, 4.00 \mathrm{~h}$ and $3.00 \mathrm{~h}$, the effluent $\mathrm{pH}$ was lower than influent $\mathrm{pH}$. As HRT shortened to $1 \mathrm{~h}$, the nitrate removal rate of S-part decreased to $31.2 \%$ and the nitrate removal ratio of E-part raised to $63.5 \%$. Due to the removal ratio $>1.09$ for E-part to S-part, this indicated that the $\mathrm{H}^{+}$generated by $\mathrm{S}$-part was inadequate for E-part consumption, resulting in the high effluent $\mathrm{pH}$.

It should be noted that over the entire studied HRT range, the $\mathrm{pH}$ in effluent of both $\mathrm{E}$ process and $\mathrm{S}+\mathrm{E}$ process under optimum applied current kept increasing with shortened HRT. The $\mathrm{pH}$ of effluent as a function of applied current at HRT $=2 \mathrm{~h}$ is shown in Fig. 6(b).

As can be seen from Fig. 6(b), the applied current has significant effect on effluent $\mathrm{pH}$. With the increase of applied current, the $\mathrm{pH}$ of effluent increase directly for both $\mathrm{E}$ process and $\mathrm{S}+\mathrm{E}$ process. In this study, $0.03 \mathrm{~mol} / \mathrm{L} \mathrm{H}_{2} \mathrm{SO}_{4}$ added in anode cell could enhance $\mathrm{H}^{+}$ transport from anode cell to cathode cell thus keeping $\mathrm{pH}$ in cathode cell in neutral. The corresponding applied current for $\mathrm{H}^{+}$transport balance was $500 \mathrm{~mA}$. As applied current exceeded $500 \mathrm{~mA}$, the inadequate $\mathrm{H}^{+}$transport from anode cell to cathode cell led to an increase of $\mathrm{pH}$ in effluent. With higher applied current, a sharp rise in effluent $\mathrm{pH}$ was observed. The effluent $\mathrm{pH}$ for $\mathrm{S}+\mathrm{E}$ process was better restrained than $\mathrm{E}$ process, indicating that the $\mathrm{H}^{+}$generated by $\mathrm{S}$ process could be consumed by E process. Thus $\mathrm{pH}$ adjustment of effluent for this combination process was achieved. For E process, the pH of effluent exceeded influent over the entire studied range (even under lower applied current: <400 mA). This was mainly due to hydrogen autotrophic denitrification process, where $\mathrm{NO}_{3}^{-}$generates equal quantity of alkalinity for complete reduction, resulting in an increase of $\mathrm{pH}$.

Considering the removal efficiency, the optimal operation parameters of combined process were: HRT $2 \mathrm{~h}$; applied current $350 \mathrm{~mA}$. Under this condition, the combined reactor could achieve 95.8\% nitrate removal rate without nitrite accumulation, the $\mathrm{pH}$ of effluent kept neutral compared with influent, and the sulfate concentration of effluent was $202.1 \mathrm{mg} / \mathrm{L}$, meeting the drinking water standard of China EPA.

\section{Conclusions}

The feasibility of PEMED system in collaboration with the sulfur denitrification process was verified in this study. The combined process had the capacity of maintaining $\mathrm{pH}$ balance thus avoiding nitrite accumulation like in the PEMED process. The sulfur autotrophic denitrification rate depended on HRT of S-part; sulfate generated during sulfur denitrification process could be controlled by HRT. The removal efficiency of E-part was controlled by applied current. The combined system could be operated at the HRT ranged from $3.00 \mathrm{~h}$ to $1.00 \mathrm{~h}$ (corresponding optimum current varied from $130 \mathrm{~mA}$ to $1300 \mathrm{~mA}$ ) with over $90 \%$ nitrate removal efficiency without nitrite accumulation, and the sulfate concentration of effluent was less than $250 \mathrm{mg} / \mathrm{L}$, meeting the drinking water standard of China EPA.

\section{Acknowledgements}

This work was supported by the National High Technology Research and Development Program of China (Grant No. 2009AA06Z307).

\section{References}

Anabela, D.F., João, G.C., Jonas, S.A., Maria, A.R., 2000. Drinking water denitrification using a novel ion-exchange membrane bioreactor. Environ. Sci. Technol. 34, 1557-1562. 
Tepuš, Brigita, Simonič, Marjana, Petrinić, Irena, 2009. Comparison between nitrate and pesticide removal from ground water using adsorbents and NF and RO membranes. J. Hazard. Mater. 170, 1210-1217.

Sahinkaya, Erkan, Hasar, Halil, Kaksonen, Anna H., Rittmann, Bruce E., 2011. Performance of a sulfide-oxidizing, sulfur-producing membrane biofilm reactor treating sulfide-containing bioreactor effluent. Environ. Sci. Technol. 45 (9), 4080-4087.

Epron, Florence, Gauthard, Florence, Pinéda, Garole, Barbier, Jacques, 2001. Catalytic reduction of nitrate and nitrite on $\mathrm{Pt}-\mathrm{Cu} / \mathrm{Al}_{2} \mathrm{O}_{3}$ catalysts in aqueous solution: role of the interaction between copper and platinum in the reaction. J. Catal. 198, 309-318.

Ghafari, S., Hasan, M., Aroua, M.K., 2008. Bio-electrochemical removal of nitrate from water and wastewater-a review. Bioresour. Technol. 99, 3965-3974.

Haugen, K.S., Semmens, M.J., Novak, P.J., 2002. A novel in situ technology for the treatment of nitrate contaminated groundwater. Water Res. 36, 3497-3506.

Kleinjans, J.C., Albering, H.J., Marx, A., Van Maanen, J.M., Van Agen, B., Ten Hoor, F., Swaen, G.M., Mertens, P.L., 1991. Nitrate contamination of drinking water: evaluation of genotoxic risk in human population. Environ. Health Persp. 1994 189-193.

Koenig, A., Liu, L.H., 2001. Kinetic model of autotrophic denitrification in sulphu packed-bed reactors. Water Res. 35 (8), 1969-1978.

Kurt, M., Dunn, J.I., Bourne, R.J., 1987. Biological denitrification of drinking wate using autotrophic organisms with $\mathrm{H}_{2}$ in a fluidized-bed biofilm reactor. Biotechnol. Bioeng. 29, 493-501.

Lee, K.C., Rittmann, B.E., 2000. A novel hollow-fiber membrane biofilm reactor for autohydrogenotrophic denitrification of drinking water. Water Sci. Technol. 41, 219-226.

Lee, K.C., Rittmann, B.E., 2003. Effects of $\mathrm{pH}$ and precipitation on autohydrogenotrophic denitrification using the hollow-fiber membranebiofilm reactor. Water Res. 37, 1551-1556.

Liu, L.H., Koenig, A., 2002. Use of limestone for $\mathrm{pH}$ control in autotrophic denitrification: batch experiments. Process Biochem. 37 (8), 885-893.

Lucas, A., De Rodríguez, L., Villaseñor, J., Fernández, F.J., 2005. Denitrification potential of industrial wastewaters. Water Res. 39, 3715-3726.

Mateju, V., Cizinska, S., Krejci, J., Janoch, T., 1992. Biological water denitrification, a review. Enzyme Microbiol. Technol. 14, 170-182.
Moon, H.S., Ahn, K.-H., Lee, S., Nam, K., Kim, J.Y., 2004. Use of autotrophic sulfuroxidizers to remove nitrate from bank filtrate in a permeable reactive barrier system. Environ. Pollut. 129 (3), 499-507.

Nolan, B.T., Ruddy, B.C., Hitt, K.J., Helsel, D.R., 1997. Risk of nitrate in groundwaters of the United States-a national perspective. Environ. Sci. Technol. 31 (8), 22292236.

Park, H.I., Kim, D.K., Choi, Y.J., Pak, D., 2005. Nitrate reduction using an electrode as direct electron donor in a biofilm-electrode reactor. Process Biochem. 40, 33833388.

Prosnansky, M., Sakakibara, Y., Kuroda, M., 2002. High-rate denitrification and SS rejection by biofilm-electrode reactor (BER) combined with microfiltration. Water Res. 36 (36), 4801-4810.

Prüsse, U., Hähnlein, M., Daum, J., Vorlop, K.-D., 2000. Improving the catalytic nitrate reduction. Catal. Today. 55 (1-2), 79-90.

Rezania, B., Oleszkiewicz, J.A., Cicek, N., 2007. Hydrogen-dependent denitrification of water in an anaerobic submerged membrane bioreactor coupled with a novel hydrogen delivery system. Water Res. 41 (19), 1074-1080.

Sakakibara, Y., Kuroda, M., 1993. Electric prompting and control of denitrification. Biotechnol. Bioeng. 42, 535-537.

Samatya, S., Kabay, N., Yüksel, Ü., Arda, M., Yüksel, M., 2006. Removal of nitrate from aqueous solution by nitrate selective ion exchange resins. React. Funct. Polym. $66,1206-1214$.

Wan, D.J., Liu, H.J., Zhao, X., Qu, J.H., Xiao, S.H., Hou, Y.N., 2009a. Role of the Mg/Al atomic ratio in hydrotalcite-supported $\mathrm{Pd} / \mathrm{Sn}$ catalysts for nitrate adsorption and hydrogenation reduction. J. Colloid. Interf. Sci. 332, 151-157.

Wan, D.J. Liu, H.J. Qu, J.H. Lei, P. X. Xiao, S.H., Hou, Y.N., 2009b. Using the combined bioelectrochemical and sulfur autotrophic denitrification system for groundwater denitrification. Bioresource Technol. 100, 142-148.

Wan, D.J., Liu, H.J., Qu, J.H., Lei, P.J., 2010. Bio-electrochemical denitrification by a novel proton-exchange membrane electrodialysis system - a batch mode study. J. Chem. Technol. Biotechnol. 85 (11), 1540-1546.

Wang, Z.S., 1998. Application of biofilm kinetics to the sulfur/lime packed bed reactor for autotrophic denitrification of groundwater. Water Sci. Technol. 37 (9), 97-104 